\title{
STRENGTHENING THE ROLE OF CORPORATE CARRIER IN THE DEVELOPMENT OF CORPORATE STUDENTS AT THE CHILDREN'S SPECIAL DEVELOPMENT INSTITUTION
}

\author{
Iqbal Kamalludin*1, Apriliani Kusumawati ${ }^{2}$, Ratna Kumala Sari ${ }^{3}$, Ayon Diniyanto ${ }^{4}$, \\ Bunga Desyana Pratami ${ }^{5}$ \\ ${ }^{1}$ Faculty of Sharia, IAIN Pekalongan, JI. Pahlawan KM 05 Rowolaku Kajen Pekalongan, Central \\ Java 51161 \\ ${ }^{2}$ Faculty of Social Sciences, Universitas Negeri Semarang, Komplek Sekaran Gunung Pati, \\ Kota Semarang, Central Java 50229 \\ ${ }^{3}$ Faculty of Law, Universitas Sang Bumi Ruwa Jurai, JI. Imam Bonjol No.486, Langkapura, Kota \\ Bandar Lampung, Lampung 35118 \\ ${ }^{4}$ Faculty of Sharia, IAIN Pekalongan, JI. Pahlawan KM 05 Rowolaku Kajen Pekalongan, Central \\ Java 51161 \\ ${ }^{5}$ Faculty of Sharia, IAIN Pekalongan, JI. Pahlawan KM 05 Rowolaku Kajen Pekalongan, Central \\ Java 51161 \\ iqbal.kamalludin@iainpekalongan.ac.id
}

\begin{abstract}
The rehabilitation approach has not become a priority for coaching so that it is difficult to change Andikpas' behavior for the better. This paper aims to describe the idea of strengthening the role of Correctional Caregivers in fostering Correctional Students at the Special Child Guidance Institution. The research method of this paper uses normative juridical with a qualitative approach. Harmonizing regulations in the correctional system is needed through legal rules in the form of special guidelines. In addition to increasing knowledge and understanding related to child protection, it is also necessary to strengthen the capacity of counseling techniques. Considering that counseling is one method that can help Andikpas to express various feelings, including the negative thoughts he feels.
\end{abstract}

Keywords: Correctional Caregivers; Juvenile Development; Juvenile Correctional

\begin{abstract}
Abstrak
Pendekatan rehabilitasi belum menjadi prioritas pembinaan sehingga perubahan perilaku Andikpas untuk menjadi lebih baik sulit terwujud. Tulisan ini bertujuan untuk mendeskripsikan gagasan penguatan peran Pengasuh Pemasyarakatan dalam pembinaan Siswa Pemasyarakatan di Lembaga Pembinaan Khusus Anak. Metode penelitian tulisan ini menggunakan yuridis normatif dengan pendekatan kualitatif. Diperlukan adanya harmonisasi peraturan dalam sistem pemasyarakatan melalui aturan hukum berupa pedoman khusus atau pengelolaan pelaksanaan tugas Pembina Pemasyarakatan untuk pembinaan Andikpas. Peningkatan pengetahuan, sikap, dan keterampilan Pembina Pemasyarakatan dalam pelaksanaan pembinaan merupakan salah satu tolak ukur keberhasilan pelaksanaan pembinaan Andikpas. Selain peningkatan pengetahuan dan pemahaman terkait perlindungan anak, perlu juga penguatan kapasitas teknik konseling. Mengingat konseling merupakan salah satu metode yang dapat digunakan untuk membantu Andikpas mengungkapkan berbagai perasaan, termasuk pikiran negatif yang dirasakannya.
\end{abstract}

Kata Kunci: Pengasuh Pemasyarakatan; Pembinaan Anak; Pemasyarakatan Anak 


\section{A. Introduction}

Children are a mandate and gift from God Almighty, who has a strategic role in ensuring the continuity of the existence of a country, thus encouraging the world community to pay attention to child protection. ${ }^{1}$ The world community has started to pay attention on the child's protection since the establishment of United Nations Declaration on the Universal Declaration of Human Rights in 1948. This declaration then underlies the ratification of the Convention on the Rights of the Child ( Convention of the Right of the Child ) by the United Nations General Assembly on November, $20^{\text {th }} 1958 .^{2}$

Indonesia regulates the principle of protection of the child is obliged to provide regulations to guarantee protection for children in all aspects of life ${ }^{3}$, including protection for children who commit criminal acts or known as Children in Conflict with the Law. One form of protection is realized through the Juvenile Criminal Justice System. ${ }^{4}$

The juvenile justice system is all elements of the criminal justice system related to handling children in conflict with the law. These elements include: First, the police as a formal institution when a child first comes into contact with the justice system, determining whether the child will be released or further processed. Second, prosecutors and parole agencies will also determine whether the child will be released or processed in juvenile court. ${ }^{5}$. The condition of the institution where the child is serving a sentence as well as a place of guidance for the child. ${ }^{6}$

The juvenile criminal justice system differs from the adult criminal justice system in many ways. Juvenile criminal justice includes all activities of examining and deciding cases aimed at the welfare of children. This is confirmed in the United Nations Standard Minimum Rules for the Administration of Juvenile Justice, that the objectives of juvenile justice are the criminal justice system for children/adolescents will prioritize the welfare of juveniles. It must be ensured that any reaction to juvenile law violations must take into account the developmental aspects of the juvenile. ${ }^{7}$

1 Direktorat Bimkemas dan Pengentasan Anak, Pedoman Perlakuan Anak Dalam Proses Pemasyarakatan Di Lembaga Pembinaan Khusus Anak (LKPA), 2015, 43.

2 Muladi and B. N. Arief, Teori-Teori Dan Kebijakan Pidana (Bandung: Alumni, 2010), 108.

3 Rafik Taufik Ahmad, "Nusantara ( Jurnal Ilmu Pengetahuan Sosial )," Nusantara: Jurnal IImu Pengetahuan Sosial 7, no. 2 (2020): 22.

4 Yutirsa Yunus, "Analisis Konsep Restorative Justice Melalui Sistem Diversi Dalam Sistem Peradilan Pidana Anak Di Indonesia," Jurnal Rechts Vinding: Media Pembinaan Hukum Nasional 2, no. 2 (2013): 232, https://doi.org/10.33331/rechtsvinding.v2i2.74.

5 A. Muin Fahmal \& Muhammad Fachri Said Andi Sefullah, "Kalabbirang Law Journal," Kalabbirang Law Journal 2, no. April (2020): 17.

6 Purniati, Analisa Situasi Sistem Peradilan Anak Di Indonesia (Jakarta: UNICEF, 2003), 5.

7 Narvedha Andriyana, "Pola Pembinaan Anak Didik Pemasyarakatan Di Lembaga Pembinaan Khusus Anak Kelas I Kutoarjo," Jurnal Komunikasi Hukum (JKH) Universitas Pendidikan Ganesha 6, no. 2 (2020): 23. 
In order to realize the welfare of children while at the same time protecting Children in Conflict with the Law, the government has issued Law Number 11 of 2012 concerning the Juvenile Criminal Justice System (UU SPPA). The SPPA Law contains the spirit of prioritizing efforts to restore justice and prevent children from the judicial process through diversion, namely the transfer of settlement of children's cases from the criminal justice process to a process outside the criminal justice system. The goal to be achieved in implementing the SPPA Law is to realize restorative justice ${ }^{8}$, namely the settlement of criminal cases by involving perpetrators, victims, families of perpetrators/victims and other relevant parties jointly seek a fair solution by restoration. in its original state, and not in retaliation. Imprisonment as a last resort.

Rutan (Rutan-Rutan)/Lapas-Lapas (Lapas-Per Lapas)/Lapas-Lapas. Special Prisons for Child Development Institutions (LPKA) throughout Indonesia. Although the SPPA Law has made imprisonment a last resort, the fact is that this is not always the case. ${ }^{9}$ This is shown by data from the Director General of the Milky Way and Child Eradication of the Ministry of Law and Human Rights in 2015 showing that there are 1,600 children in conflict with the law spread over 457 Detention Centers (Rutan-Rumah Tahanan) / Correctional Institutions (LapasLembaga Permasyarakatan) / Special Child Development Institutions (LPKA-Lembaga Permasyarakatan Khusus Anak) throughout Indonesia. ${ }^{10}$

In the Juvenile Criminal Justice System, Prisons/Rutan/LPKA are institutions where children serve their sentences and play an important role in the development of children. Guidance for $\mathrm{ABH}$ has the aim of returning them as members of the community and reducing the potential for repeating criminal acts. ${ }^{11}$ Legal products in Indonesia relating to the development of Children in Conflict with the Law in Rutan/Lapas/LPKA are regulated in Law Number 12 of 1995 concerning Corrections, Law Number 11 of 2012 concerning the Juvenile Criminal Justice System, and Law Number 35 of 2014 concerning Amendments to Law Number 23 of 2002 concerning Child Protection. ${ }^{12}$

8 Hafiidh Fajar Bahari, "Perlindungan Narapidana Anak Di Lembaga Pemasyarakatan Kelas lib Jombang," Recidive 4, no. 3 (2015): 440.

9 Riccy Antar Budaya, "Aspek Hukum Keterkaitan Konsep Pemasyarakatan Dengan Perlindungan Anak Dalam Pembinaan Narapidana Anak Di Lembaga Pemasyarakatan,” 2013, 12.

10 Jumlah anak pidana per Maret 2018 berdasarkan Data Sistem Database Pemasyarakatan diakses di laman http://smslap.ditjenpas.go.id/public/arl/current/monthly/year/2018/month/3 pada tanggal $23 \mathrm{Juni}$ 2018

11 Oki Wahju Budijanto, "Pemenuhan Hak Pendidikan Bagi Anak Didik Pemasyarakatan Di Lembaga Pembinaan Khusus Anak," Pemenuhan Hak Pendidikan Bagi Anak Didik Pemasyarakatan Di Lembaga Pembinaan Khusus Anak 7, no. 1 (2013): 67, jU.

12 Erpis Candra, "Implementasi Kewajiban Pembinaan Terhadap Pidana Anak Di Lembaga Pembinaan Khusus Anak Pekanbaru Berdasarkan Undang-Undang Republik Indonesia Nomor 11 Tahun 2012 Tentang Sistem Peradilan Pidana Anak," Widya Yuridika 3, no. 2 (2020): 343, https://doi.org/10.31328/wy.v3i2.1642. 
The existence of a legal basis in the form of a coaching mechanism for Children in Conflict with the Law in Rutan/Lapas/LPKA does not guarantee the success of the coaching process. The National Commission for Children reported that the number of reporting children in conflict with the law was 52 percents dominated by theft cases, followed by other cases such as drugs, child protection, traffic rules violations, robbery, and murder. In the case of theft, as many as 42.8 percents are recidivist perpetrators. ${ }^{13}$ This phenomenon shows that the process of fostering Andikpas in Correctional Institutions is still not effective.

Yusti Probowati conveyed in the Workshop on Model Development of Child Correctional Institutions regarding the results of his study of the problems in LPKA as follows: ${ }^{14}$ the existence of recidivists and the relatively stable number of prisoners are an indication that the development system so far has not been optimal, there are no clear criteria for success and failure, the number of security officers is more than the number of rehabilitation officers, the ratio of rehabilitation officers is not proportional to the number of prisoners. This shows that the security approach is more dominant than the rehabilitation approach, the rehabilitation implemented is still far from the rehabilitation concept that should be due to the lack of qualified personnel, there is still physical violence as a way of giving punishment under the pretext of coaching, lack of infrastructure that hinders the development process, lack of coordination of the coaching system within the institution and coaching outside the institution.

Furdyartanto in his book "Psychology of Education with a New Approach" reveals that the LPKA situation still has the potential to hinder the effectiveness of the rehabilitation and reintegration process for children, for example ${ }^{15}$ a climate that does not guarantee that children can socialize well, the supervisory officer does not have knowledge of the child's mental or psychological health so that they do not know the child's psychological condition, the coaching staff does not understand what each child really needs; and the curriculum of coaching materials and facilities do not help the child's personality development.

The facts mentioned above indicate that one of the causes of ineffective coaching is the officers. Officers have an important role when children are undergoing a period of coaching in the Rutan/Lapas/LPKA/. The success of the coaching process depends on the approach

13 Dyana C Jatnika, Nandang Mulyana, and Santoso Tri Raharjo, "Didik Lembaga Pemasyarakatan Dalam Menghadapi Proses," in Prosiding Penelitian Dan Pengabdian Kepada Masyarakat, 2016, 261.

14 Fanny Tanuwijaya. 2009. Pembinaan Anak di Lembaga Pemasyarakatan Anak dalam Rangka Pembinaan Anak Pidana. Disertasi Program Doktor IImu Hukum Fakultas Hukum Universitas Brawijaya Malang. p.8

15 Abintoro Prakoso, Pembaruan Sistem Peradilan Pidana Anak (Yogyakarta: Laksbang Grafika, 2013), 245. 
chosen by the officers in the coaching process. ${ }^{16}$ Unfortunately, currently, the security approach is still the benchmark for the success of the correctional system, even though outreach to the psychological side and behavior change of Andikpas cannot only be done with a repressive or security approach. The rehabilitation approach has not become a coaching priority so that changes in Andikpas behavior for the better will be difficult to materialize. Based on this background, the author wants to conduct a study on strengthening the role of officers, in the case of Correctional Caregivers, in fostering Andikpas in Rutan/Lapas/LPKA. ${ }^{17}$ Based on these problems, the authors feel it is important to raise the formulation of the problem, the role of the Correctional Supervisor in fostering Correctional Students at the Special Child Guidance Institution, and efforts to strengthen the role of the Correctional Counselor in fostering the Correctional Child in the Child Special Guidance Institution.

\section{B. Discussion}

\section{The Role of Correctional Caregivers in the Guidance of Correctional Students in Special Child Guidance Institutions}

Criminal punishment is suffering that is intentionally imposed on someone who violates the provisions of the law. ${ }^{18}$ The purpose of giving a criminal or sentencing basically contains 2 (two) main aspects, among others, the first is as an effort to protect the community against criminal acts, including crime prevention, community protection, restoring community balance, in the form of conflict resolution and creating a sense of peace (vrede making) ${ }^{19}$. Second, the aspect of protection/guidance of individual perpetrators of criminal acts, including how to socialize prisoners through rehabilitation, re-education, re-socialization so that they do not commit acts that harm themselves and others and have a Pancasila character, absolve wrongdoers, protect perpetrators from the imposition of arbitrary sanctions or inhuman retaliation. This right is carried out because punishment is not intended to degrade human dignity.

As an integral part of the Criminal Justice System, Corrections play a very important role in achieving the goals of punishment. The implementation of correctional institutions, especially for Children in Conflict with the Law, aims to restore them as citizens of the community and

${ }^{16}$ Chusniatun, "Sistem Perlindungan Hukum Bagi Anak Di Lembaga Pemasyarakatan Dalam Perspektif Konvensi Internasional Hak-Hak Anak," Suhuf 30, no. 01 (2018): 107.

17 Fransiska Novita Eleanora and Esther Masri, "Pembinaan Khusus Anak Menurut Sistem Peradilan Pidana Anak," Jurnal Kajian IImiah Universitas Bhayangkara Jakarta Raya 18, no. 3 (2018): 222.

18 Muladi and Arief, Teori-Teori Dan Kebijakan Pidana, 2.

19 Barda Nawawi Arief, Tujuan Dan Pedoman Pemidanaan: Perspektif Pembaharuan Dan Perbandingan Hukum Pidana (Semarang: Pustaka Magister, 2017), 37. 
reduce the potential for repeating criminal acts. Children in Conflict with the Law who are in the correctional system are known as Correctional Students (Andikpas). ${ }^{20}$

The legal basis in Indonesia relating to the development of Andikpas in Rutan/Lapas/LPKA is contained in Law Number 12 of 1995 concerning the Correctional System (Penal Code) and Law Number 11 of 2012 concerning the Juvenile Criminal Justice System (UU SPPA). The Correctional Law and the SPPA Law have the same scope in terms of fulfilling the rights of Andikpas who get imprisonment. ${ }^{21}$

Law Number 12 of 1995 concerning Corrections (Penitentiary Law) stipulates that Correctional Students are children who based on a court decision are serving a sentence in a Juvenile Prison for a maximum of 18 (eighteen) years. ${ }^{22}$ The sentencing of Andikpas is an effort to make Andikpas realize that he regrets his actions and can return to being law-abiding citizens. ${ }^{23}$ Coaching for Andikpas certainly has its own peculiarities according to the condition of the child. ${ }^{24}$

The Correctional Law formulates a coaching mechanism in the form of rehabilitation and reintegration of children.Although specifically not separated between the affairs of children and adults. ${ }^{25}$ The purpose of this penitentiary system is to shape the child into a complete human being; realize mistakes; improve oneself; and do not repeat the crime. Meanwhile, in the reintegration process, it is intended that the child can be accepted again by the community; can play an active role in development; can live naturally as good and responsible citizens. ${ }^{26}$

Article 5 of the Correctional Law states that the correctional development system is carried out based on the principles of protection, equality of treatment and service, education, guidance, respect for human dignity and dignity. In this case, deprivation of liberty is the only suffering, but it is still guaranteed by the right to care, and does not cut ties with family or certain people. ${ }^{27}$

20 Rifky Taufiq Fardian and Meilanny Budiarti Santoso, "Pemenuhan Hak Anak Yang Berhadapan (Berkonflik) Dengan Hukum Di Lembaga Pembinaan Khusus Anak (Lpka) Kelas li Bandung," Jurnal Kolaborasi Resolusi Konflik 2, no. 1 (2020): 7, https://doi.org/10.24198/jkrk.v2i1.27043.

21 Egitya Firdausyah and Mitro Subroto, "Pemasyarakatan Di Lembaga Pembinaan Khusus Anak Kelas I Kutoarjo," Supremasi Jurnal Hukum 04, no. 1 (2015): 42.

22 Hafrida Hafrida, Yulia Monita, and Elisabeth Siregar, "Pembinaan Narapidana Anak Di Lembaga Pemasyarakatan Anak Sei. Bulu Muara Bulian," Publikasi Pendidikan 5, no. 3 (2015): 211, https://doi.org/10.26858/publikan.v5i3.1613.

23 Sri Haryaningsih and Titik Hariyati, "Resosialisasi Di Lembaga Pemasyarakatan Khusus Anak," Jurnal Konseling Dan Pendidikan 8, no. 3 (2020): 192, https://doi.org/10.29210/151300.

24 Loura Hardjaloka, "Criminal Justice System of Children: An Overview Restorative Justice Concept in Indonesia and Other Countries," Journal of Dinamika Hukum 15, no. 1 (2015): 77, http://dinamikahukum.fh.unsoed.ac.id/index.php/JDH/article/view/365/359.

25 Dwike Putri Hilman and Endang Sri Indrawati, "Pengalaman Menjadi Narapidana Remaja Di Lapas Klas I Semarang," Empati 6, no. 3 (2017): 197.

26 Pasal 2 Undang-undang Nomor 12 Tahun 1995 tentang Pemasyarakatan

27 Hizkia Brayen Lumowa, "Hak Pendidikan Bagi Narapidana Anak Ditinjau Dari Undang-Undang Nomor 35 Tahun 2014 Tentang Perlindungan Anak," Lex Privatum 3, no. 1 (2017): 108. 
The coaching system is carried out on prisoners and Andikpas which are then regulated in government regulations. ${ }^{28}$

The regulation of the implementation of the duties and functions of fostering children refers to the implementing regulations of the Correctional Law, namely Government Regulation Number 31 of 1999 concerning the Guidance and Guidance of Correctional Inmates and Government Regulation Number 58 of 1999 concerning Conditions and Procedures for the Implementation of the Authority, Duties and Responsibilities of Care Prisoner. ${ }^{29}$ The two legal regulations have stated the minimum prerequisites and procedures at each stage of the coaching process. However, in its description, the article does not provide a special regulatory space for the coaching and reintegration of Andikpas. ${ }^{30}$

The role of coaching in Rutan/Lapas/LPKA is ideally present in the figure of a coaching officer known as the Correctional Guardian or Correctional Caregiver. Based on a literature search, the rules regarding Correctional Guardians or Correctional Caregivers are contained in the Regulation of the Minister of Law and Human Rights of the Republic of Indonesia Number M.01 PK.04.10 of 2007 concerning Correctional Guardians and Guidelines for the Treatment of Children in LPKA issued by the Directorate of Public Health and the Directorate General of PAS. $^{31}$

Article 1 of the Regulation of the Minister of Law and Human Rights of the Republic of Indonesia Number M.01 PK.04.10 of 2007 concerning Correctional Guardians states that what is meant by Correctional Guardians are Correctional Officers who provide assistance to Prisoners and Correctional Students while undergoing guidance in Correctional Institutions. Furthermore, the duties and authorities of the correctional guardian are described in Article 2.

Community Caregivers according to this guideline are Andikpas assistants or adult prisoners in the process of undergoing coaching, including when interacting with fellow residents, officers, families, or the community. The Correctional Caregiver exercises parental powers over Andikpas.

28 Nurul Chaerani Nur And Asdar Djabar, "Perlindungan Hukum Dan Pembinaan Anak Didik Pemasyarakatan Di Lembaga Pemasyarakatan Klas lib Biak Berdasarkan Undang-Undang Nomor 12 Tahun 1995 Tentang Pemasyarakatan," Jurnal IImu Hukum Kyadiren 2, no. November (2019): 70, https://media.neliti.com/media/publications/300401-perlindungan-hukum-dan-pembinaan-anak-dife712654.pdf.

29 Enny Nurbaningsih, "Naskah Akademik Rancangan Undang-Undang Tentang Pemasyarakatan," 2017, 13.

30 Sasmita, Dian. 2015. Reformasi Sistem Pemasyarakatan yang Berspektif Perlindungan Anak (Studi Kasus di Rutan Klas I Surakarta dan Lapas Klas IIB Klaten). Thesis Program Pascasarjana Fakultas Hukum Universitas Sebelas Maret Surakarta. 71

31 Gemala Nurendah, Muhammad Ariez Musthofa, and Sri Maslihah, "Model Pengasuhan Bagi Anak Didik Lpka," Jurnal Psikologi Insight 3, no. 2 (2019): 85, https://doi.org/10.17509/insight.v3i2.22348. 
Correctional Caregivers have the task of providing support for the implementation of rehabilitation, including recording and evaluating the progress of each Andikpas based on laws. The report from the Correctional Caregiver becomes one of the materials for the Correctional Observer Team in making recommendations for their treatment. Furthermore, the arrangements regarding Correctional Caregivers are listed in the Guidelines for the Treatment of Children at LPKA as follows:

In each institution must be appointed several Correctional Caregivers who are specially trained and are officers from the coaching section. Correctional Caregivers are appointed by the Head of Rutan/Lapas/LPKA to take care of Andikpas and provide support for implementing the coaching program plan.

Correctional Caregivers assist Andikpas to identify and meet the objectives set out in the case management plan, as well as in applying for leave or for complaint processing, early release, and to assist Andikpas in general for any identified needs.

Correctional Caregivers must be appointed at a reasonable ratio for the number of children, at least one Correctional Caregiver per 10 Andikpas. In addition, there must be at least 2 (two) full-time Correctional Caregivers at LPKA to serve Andikpas care needs within 24 hours.

The Correctional Caregiver must check each Andikpas under his guidance and make notes on the progress of each Andikpas every week in the Andikpas file. These records are to be reviewed at the monthly meeting held by Correctional Caregivers.

Correctional Caregivers are supervised by officials in the coaching section and are responsible to the Head of LPKA

In practice, the role of Correctional Caregivers has not been optimal in guiding Andikpas. Rapid Assessment Report on the Fulfillment of Children's Right to Health and Welfare in Central Java Province in $2015^{32}$ shows that child care in LPKA has several challenges, including:

The Correctional Caregiver function is an additional function that is attached to officers and has not been supported by special allowances.

There are not yet available supporting tools for Correctional Caregivers such as codes of ethics and Standard Operating Procedures (SOP). So far, Correctional Caregivers are still using the device to assest adult inmates. Each Correctional Caregiver also develops its own method that prioritizes a personal approach to the Child. ${ }^{33}$

32 Penelitian dilakukan oleh Kementerian Pemberdayaan Perempuan dan Perlindungan Anak Republik Indonesia bekerjasama dengan Lembaga Swadaya Masyarakat Yayasan Sahabat Kapas dengan lokasi penelitian di Lembaga Pembinaan Khusus Anak Klas I Kutoarjo.

33 Farrah Syamala Rosyda, "Implementasi Pemenuhan Hak Pendidikan Untuk Anak Pidana Di Lembaga Pembinaan Khusus Anak Kutoarjo," Amnesti Jurnal Hukum 2, no. 1 (2020): 54, https://doi.org/10.37729/amnesti.v2i1.651. 
Most of the Correctional Caregivers have never received child protection training. There is no internalization activity initiated by LPKA Class I Kutoarjo itself. Whereas the Correctional Caregiver's knowledge of child protection, especially children's rights and their fulfillment is one of the important keys to determine the success of the implementation of coaching. Mainstream as a Child prison is still very strong.

Research conducted by Dian Sasmita shows the same thing. ${ }^{34}$ The Surakarta Class I Rutan and Klaten Class IIB Prisons already have Correctional Caregivers that are not specifically intended for Andikpas. The appointment of Correctional Caregivers is carried out through internal policies such as the Decree of the Head of the Klaten Correctional Institution Number W9.EW.PK.05.01.03-1152 of 2012 concerning the Appointment of Correctional Caregivers. In practice, the role of Correctional Caregivers in Rutan/Lapas has not been optimal in providing personal guidance for Andikpas. Andikpas' relationship with the Correctional Caregiver is only limited to applying for remission or other rights. There are no specific guidelines for the work of Correctional Caregivers related to the Andikpas guidance program.

Although there are arrangements regarding Correctional Guardians or Correctional Caregivers, there are no specific guidelines or procedures for carrying out the duties of Correctional Caregivers for the guidance of Andikpas. This shows that the harmonization of regulations in the correctional system with other legal rules regarding the development of Andikpas has not been implemented. As a result, the guidance and fulfillment of Andikpas rights are very vulnerable to not being fulfilled by the state. ${ }^{35}$

\section{Efforts to Strengthen the Role of Correctional Caregivers in the Guidance of Correctional Students in Special Child Guidance Institutions}

The Criminal Justice System is an inseparable part of various subsystems or components consisting of a substantive legal component (legal substance), namely statutory norms, a legal structure component including law enforcement agencies or officers, and a legal culture component (legal structure). culture) namely the values of legal philosophy, legal values that live in society and awareness of legal behavior, as well as legal education. ${ }^{36}$

34 Sasmita, Dian. 2015. Reformasi Sistem Pemasyarakatan yang Berspektif Perlindungan Anak (Studi kasus di Rutan Klas I Surakarta dan Lapas Klas IIB Klaten). Thesis Program Pascasarjana Fakultas Hukum Universitas Sebelas Maret Surakarta. HIm 65

35 Ismail Rumadan, "Problem Lembaga Pemasyarakatan Di Indonesia Dan Reorientasi Tujuan Pemidanaan," Jurnal Hukum Dan Peradilan 2, no. 2 (2013): 263, https://doi.org/10.25216/jhp.2.2.2013.263-276.

36 Barda Nawawi Arief, Reformasi Sistem Peradilan (Sistem Penegakan Hukum Di Indonesia) (Semarang: Badan Penerbit Universitas Diponegoro, 2017), 3. 
The close interrelationships between the three components mentioned above can be illustrated as is the case with a car running system. If the law is illustrated as a tool or means in the form of a car to achieve a certain goal, then enforcing or implementing the law is essentially identical to running a car. A car or vehicle that is identical to the component of legal substance (legal substance) can only run if there is a driver. Drivers who are identical with structural components (legal structure) must master the knowledge of running a car which is included in the cultural component (legal culture). Mastery of the science of running a car is shown by the existence of a Driving License (SIM-Surat Izin Mengemudi). It should be emphasized, that the SIM alone is certainly not enough. The driver must also know and master the science or environmental conditions. If not, then the driver could be in the wrong direction or the wrong way. This means that criminal law enforcement must also pay attention to the Indonesian context, especially the condition of the Indonesian legal environment, namely the National Legal System. ${ }^{37}$

Departing from the notion of an integral system, the understanding of the Criminal Justice System or Law Enforcement System can be seen from its various components. When viewed from the legal substance component, the Criminal Justice System or Law Enforcement System is essentially a system for enforcing legal substance in the field of criminal law, including material criminal law, formal criminal law, and criminal law enforcement. The Criminal Justice System or the Law Enforcement System in terms of legal substance is essentially an integrated legal system or integrated legal substance. When viewed from the structural component (legal structure), the Criminal Justice System or Law Enforcement System is basically a system for the running or functioning of bodies, institutions, law enforcement officers in carrying out their respective functions or authorities in the field of law enforcement.

Structurally, the Criminal Justice System or Law Enforcement System is also an administrative system or functional system of various law enforcement structures, so that the term integrated criminal justice system or criminal justice administration consists of 4 (four) subsystems, namely: the authority of investigation by the investigating agency or institution ; power of attorney by the public prosecutor's body or institution; the power to hear and impose decisions or sentences by the judiciary; and the power to carry out a decision or crime by the agency or apparatus or implementing agency.

When viewed from the cultural component (legal culture), the Criminal Justice system or Law Enforcement System is basically the embodiment of a system of legal cultural values that

37 Deotrich Sammuel Sahetapy, Sherly Adam, and Hadibah Zachra Wadjo, "Penjatuhan Sanksi Bagi Anak Didik Pemasyarakatan Pasca Melarikan Diri ( Studi Pada Lembaga Pembinaan Khusus Anak Kelas II Ambon )," Tatohi Jurnal IImu Hukum 1, no. 5 (2021): 448-59. 
can include legal philosophy, legal principles, legal theory, legal science, and legal awareness or behavior. The Criminal Justice System or Law Enforcement System from the point of view of legal culture can be said to be an integrated legal culture or an integrated cultural law system. ${ }^{38}$

In addition, it is also necessary to have a synchronization that contains the meaning of simultaneously and harmony, both structural synchronization, substantive synchronization, and cultural synchronization ${ }^{39}$ as in structural synchronization demands uniformity and harmony in the administration of criminal justice within the framework of the relationship between law enforcement, substantial synchronization demands synchrony and alignment both vertically and horizontally in relation to the applicable positive law, cultural synchronization implies an effort to always simultaneously live up to the views, attitudes, and philosophies that underlie the criminal justice system as a whole.

Starting from the description of the first discussion and understanding related to the unity of the Criminal Justice System ${ }^{40}$, strengthening the role of Correctional Caregivers is an urgent matter in renewing the coaching approach for Andikpas. Such strengthening can be done, among others, through the substance component (legal substance) is in the form of legal norms that function as a basis that contains obligations or rules and has binding power. This legal norm becomes a guideline for the implementing apparatus. Although there are regulations regarding Correctional Guardians or Correctional Trustees in the Correctional Law and Guidelines for the Treatment of Children in LPKA issued by the Directorate of Public Health and the Directorate General of Corrections, there are no specific guidelines or procedures for its implementation. Duty. Correctional Trustees to foster Andikpas. This shows that the harmonization of regulations in the correctional system with other legal rules regarding the development of Andikpas has not been implemented.

The structural component regulates how the law is carried out in accordance with existing formal provisions. Included in the structure are what can and cannot be done, how is the availability of quality human resources and supporting facilities, how existing institutions carry out their functions, and how the existing budget is. Components in the structure support the movement of elements of substance or legal norms.

38 Ferdy Saputra, "Peranan Lembaga Pemasyarakatan Dalam Proses Penegakan Hukum Pidana Dihubungkan Dengan Tujuan Pemidanaan," REUSAM: Jurnal Ilmu Hukum 8, no. 1 (2020): 12, https://doi.org/10.29103/reusam.v8i1.2604.

39 Jaya, Nyoman Serikat Putra. 2018. Materi Kuliah Sistem Peradilan Pidana Magister IImu Hukum Universitas Diponegoro: Sistem Peradilan Pidana (Criminal Justice System).p.23

40 Iqbal Kamalludin and Barda Nawawi Arief, "Kebijakan Formulasi Hukum Pidana Tentang Penanggulangan Tindak Pidana Penyebaran Ujaran Kebencian (Hate Speech) Di Dunia Maya," Law Reform 15, no. 1 (2019): 15, https://doi.org/10.14710/lr.v15i1.23358. 
Many factors that affect the effectiveness of a legislation are professional and optimal implementation of the roles, authorities, and functions of the apparatus. ${ }^{41}$ Based on the SPPA Law, the Correctional Law and Guidelines for the Treatment of Children in LPKA, the role of fostering Andikpas is the responsibility of the Correctional Caregiver. Optimizing the role of Correctional Caregivers is needed through the quality of human resources who have an understanding of children's rights and counseling skills. The need for human resources with such qualifications is paramount considering the importance of fulfilling the right to care for children as long as they are separated from their families.

Service management by Andikpas coaching officers requires special quality standards in the Standard Operating Procedures (SOP), which also explain who the officers are and their duties. The SOP describes the duties and obligations of the Correctional Caregiver at each stage of development. As a result, the availability of SOPs to become a Correctional Caregiver understands what to do and what not to do in the coaching process, including minimizing neglect of the fulfillment of rights for Andikpas. ${ }^{42}$

In addition, it is also important to organize regular capacity-building activities for Correctional Caregivers. Improving the knowledge, attitudes, and skills of Correctional Caregivers in the implementation of coaching is a benchmark for the success of the implementation of Andikpas coaching. In addition to increasing knowledge and understanding related to child protection, it is also necessary to strengthen the capacity of counseling techniques. Considering that counseling is one method that can help Andikpas express various feelings, including the negative thoughts he feels. By understanding counseling techniques, Correctional Caregivers are expected to be able to provide psychological assistance appropriately and correctly for Andikpas.

Elements of legal culture concern the laws that are adhered to in a society (living law), including human attitudes or society. No matter how well the substance is made and the structure is carried out without being supported by the legal culture of the individuals in it, a system will not work effectively.

The security approach has become a common culture in prisons/detention centers. Changes in perspective are carried out through periodic training of officers/coaches and a code of conduct that respects individual dignity. Rehabilitation and reintegration efforts are expected to be realized along with the reduced impact of prisonization on Andikpas.

41 Achmad Ali, Teori Hukum (Legal Theory) Dan Teori Peradilan (Jurisprudence), Termasuk Interpretasi Undang-Undang (Legisprudence) (Jakarta: Kencana Prenada Media Group, 2009), 376.

42 Habibah Mutiara Triano et al., "Pemenuhan Hak Pengasuhan Bayi Oleh Pemasyarakatan Perempuan Kelas II A Tangerang," PEKSOS: Jurnal IImiah Pekerjaan Sosial 19, no. 1 (2020): 110. 


\section{Conclusion}

The absence of specific guidelines or procedures for carrying out the duties of Correctional Caregivers for the development of Correctional Students (Andikpas) shows that the harmonization of regulations in the correctional system with other legal rules regarding Andikpas development has not been implemented. Second, the security approach is still being applied in the correctional system. The rehabilitation paradigm has not been a priority for guidance by the Correctional Caregivers so that changes in Andikpas' behavior for the better will be difficult to realize.

Strengthening the role of Correctional Caregivers is an urgent matter in renewing the coaching approach for Andikpas. Strengthening can be done with several approaches, namely harmonization of regulations in the correctional system through legal rules in the form of special guidelines or management of the implementation of the Correctional Caregiver duties for fostering Andikpas. This is intended so that the development and fulfillment of Andikpas rights can be carried out effectively. Optimizing the role of Correctional Caregivers can be done through improving the quality of Correctional Caregivers on a regular basis. Improvement of knowledge, attitudes, and skills of Correctional Caregivers in the implementation of coaching is a benchmark for the success of the implementation of Andikpas coaching. In addition to increasing knowledge and understanding related to child protection, it is also necessary to strengthen the capacity of counseling techniques. Considering that counseling is one method that can be used to help Andikpas express various feelings, including the negative thoughts he feels. By understanding counseling techniques, Correctional Caregivers are expected to be able to provide psychological assistance appropriately and correctly for Andikpas.

\section{REFERENCES}

\section{Book:}

Ali, A. (2009). Teori Hukum (Legal Theory) Dan Teori Peradilan (Jurisprudence), Termasuk Interpretasi Undang-Undang (Legisprudence). Jakarta: Kencana Prenada Media Group.

Anak, DBP. (2019). Pedoman Perlakuan Anak Dalam Proses Pemasyarakatan Di Lembaga Pembinaan Khusus Anak (LKPA). Jakarta: LKPA.

Arief, BN. (2017). Reformasi Sistem Peradilan (Sistem Penegakan Hukum Di Indonesia). Semarang: Badan Penerbit Universitas Diponegoro.

(2017). Tujuan Dan Pedoman Pemidanaan: Perspektif Pembaharuan Dan Perbandingan Hukum Pidana. Semarang: Pustaka Magister.

Muladi, and B. N. Arief. (2010). Teori-Teori Dan Kebijakan Pidana. Bandung: Alumni. 
Prakoso, A. (2013). Pembaruan Sistem Peradilan Pidana Anak. Yogyakarta: Laksbang Grafika.

Purniati. (2003). Analisa Situasi Sistem Peradilan Anak Di Indonesia. Jakarta: UNICEF.

\section{Journal:}

Ahmad, RT. "Nusantara ( Jurnal Ilmu Pengetahuan Sosial )." Nusantara: Jurnal IImu Pengetahuan Sosial 7, no. 2 (2020): 408-20.

Andi, S, A. Muin Fahmal \& Muhammad Fachri Said. "Kalabbirang Law Journal." Kalabbirang Law Journal 2, no. April (2020): 14-21.

Andriyana, N. "Pola Pembinaan Anak Didik Pemasyarakatan Di Lembaga Pembinaan Khusus Anak Kelas I Kutoarjo." Jurnal Komunikasi Hukum (JKH) Universitas Pendidikan Ganesha 6, no. 2 (2020): 592-99.

Bahari, H F. "Perlindungan Narapidana Anak Di Lembaga Pemasyarakatan Kelas lib Jombang." Recidive 4, no. 3 (2015): 337-44.

Budaya, R A. "Aspek Hukum Keterkaitan Konsep Pemasyarakatan Dengan Perlindungan Anak Dalam Pembinaan Narapidana Anak Di Lembaga Pemasyarakatan,” 2013.

Budijanto, O W. "Pemenuhan Hak Pendidikan Bagi Anak Didik Pemasyarakatan Di Lembaga Pembinaan Khusus Anak." Pemenuhan Hak Pendidikan Bagi Anak Didik Pemasyarakatan Di Lembaga Pembinaan Khusus Anak 7, no. 1 (2013): 62-73. jU.

Candra, E. "Implementasi Kewajiban Pembinaan Terhadap Pidana Anak Di Lembaga Pembinaan Khusus Anak Pekanbaru Berdasarkan Undang-Undang Republik Indonesia Nomor 11 Tahun 2012 Tentang Sistem Peradilan Pidana Anak." Widya Yuridika 3, no. 2 (2020): 343. https://doi.org/10.31328/wy.v3i2.1642.

Chusniatun. "Sistem Perlindungan Hukum Bagi Anak Di Lembaga Pemasyarakatan Dalam Perspektif Konvensi Internasional Hak-Hak Anak." Suhuf 30, no. 01 (2018): 103-32.

Eleanora, F N, and Esther Masri. "Pembinaan Khusus Anak Menurut Sistem Peradilan Pidana Anak." Jurnal Kajian IImiah Universitas Bhayangkara Jakarta Raya 18, no. 3 (2018): 21530.

Fardian, Rifky Taufiq, and Meilanny Budiarti Santoso. "Pemenuhan Hak Anak Yang Berhadapan (Berkonflik) Dengan Hukum Di Lembaga Pembinaan Khusus Anak (Lpka) Kelas li Bandung." Jurnal Kolaborasi Resolusi Konflik 2, no. 1 (2020): 7. https://doi.org/10.24198/jkrk.v2i1.27043.

Firdausyah, E, and Mitro Subroto. "Pemasyarakatan Di Lembaga Pembinaan Khusus Anak Kelas I Kutoarjo." Supremasi Jurnal Hukum 04, no. 1 (2015): 31-45.

Hafrida, H, Yulia Monita, and Elisabeth Siregar. "Pembinaan Narapidana Anak Di Lembaga Pemasyarakatan Anak Sei. Bulu Muara Bulian." Publikasi Pendidikan 5, no. 3 (2015): 198-213. https://doi.org/10.26858/publikan.v5i3.1613.

Hardjaloka, L. "Criminal Justice System of Children: An Overview Restorative Justice Concept in Indonesia and Other Countries." Journal of Dinamika Hukum 15, no. 1 (2015): 73-81. http://dinamikahukum.fh.unsoed.ac.id/index.php/JDH/article/view/365/359. 
Haryaningsih, S, and Titik Hariyati. "Resosialisasi Di Lembaga Pemasyarakatan Khusus Anak." Jurnal Konseling Dan Pendidikan 8, no. 3 (2020): 191. https://doi.org/10.29210/151300.

Hilman, D P, and Endang Sri Indrawati. "Pengalaman Menjadi Narapidana Remaja Di Lapas Klas I Semarang." Empati 6, no. 3 (2017): 189-203.

Jatnika, D C, Nandang Mulyana, and Santoso Tri Raharjo. "Didik Lembaga Pemasyarakatan Dalam Menghadapi Proses." In Prosiding Penelitian Dan Pengabdian Kepada Masyarakat, 261, 2016.

Kamalludin, I, and Barda Nawawi Arief. "Kebijakan Formulasi Hukum Pidana Tentang Penanggulangan Tindak Pidana Penyebaran Ujaran Kebencian (Hate Speech) Di Dunia Maya." Law Reform 15, no. 1 (2019): 113. https://doi.org/10.14710/lr.v15i1.23358.

Lumowa, H B. "Hak Pendidikan Bagi Narapidana Anak Ditinjau Dari Undang-Undang Nomor 35 Tahun 2014 Tentang Perlindungan Anak." Lex Privatum 3, no. 1 (2017): 103-11.

Nur, N C, and Asdar Djabar. "Perlindungan Hukum Dan Pembinaan Anak Didik Pemasyarakatan Di Lembaga Pemasyarakatan Klas lib Biak Berdasarkan UndangUndang Nomor 12 Tahun 1995 Tentang Pemasyarakatan." Jurnal IImu Hukum Kyadiren 2, no. November (2019): 64-77. https://media.neliti.com/media/publications/300401perlindungan-hukum-dan-pembinaan-anak-di-fe712654.pdf.

Nurendah, G, Muhammad Ariez Musthofa, and Sri Maslihah. "Model Pengasuhan Bagi Anak Didik Lpka." Jurnal Psikologi Insight 3, no. 2 (2019): 80-87. https://doi.org/10.17509/insight.v3i2.22348.

Rosyda, F S. "Implementasi Pemenuhan Hak Pendidikan Untuk Anak Pidana Di Lembaga Pembinaan Khusus Anak Kutoarjo." Amnesti Jurnal Hukum 2, no. 1 (2020): 43-56. https://doi.org/10.37729/amnesti.v2i1.651.

Rumadan, I. "Problem Lembaga Pemasyarakatan Di Indonesia Dan Reorientasi Tujuan Pemidanaan." Jurnal Hukum Dan Peradilan 2, no. 2 (2013): 263. https://doi.org/10.25216/jhp.2.2.2013.263-276.

Sahetapy, D S, Sherly Adam, and Hadibah Zachra Wadjo. "Penjatuhan Sanksi Bagi Anak Didik Pemasyarakatan Pasca Melarikan Diri ( Studi Pada Lembaga Pembinaan Khusus Anak Kelas II Ambon )." Tatohi Jurnal IImu Hukum 1, no. 5 (2021): 448-59.

Saputra, F. "Peranan Lembaga Pemasyarakatan Dalam Proses Penegakan Hukum Pidana Dihubungkan Dengan Tujuan Pemidanaan." REUSAM: Jurnal IImu Hukum 8, no. 1 (2020): 1. https://doi.org/10.29103/reusam.v8i1.2604.

Triano, H M, Politeknik Kesejahteraan, Sosial Bandung, Moch Zaenal Hakim, Politeknik Kesejahteraan, Sosial Bandung, Enung Huripah, et al. "Pemenuhan Hak Pengasuhan Bayi Oleh Pemasyarakatan Perempuan Kelas II A Tangerang." PEKSOS: Jurnal IImiah Pekerjaan Sosial 19, no. 1 (2020): 99-112.

Yunus, Y. "Analisis Konsep Restorative Justice Melalui Sistem Diversi Dalam Sistem Peradilan Pidana Anak Di Indonesia." Jurnal Rechts Vinding: Media Pembinaan Hukum Nasional 2, no. 2 (2013): 231. https://doi.org/10.33331/rechtsvinding.v2i2.74. 